\title{
PRIORITY DIRECTIONS OF EXPENDITURE IN THE OPINION OF RESIDENTS OF SELECTED RURAL COMMUNES OF THE LUBELSKIE VOIVODESHIP
}

\author{
Agnieszka Komor, $\mathrm{PhD}^{1}$ \\ Faculty of Agrobioengineering, University of Life Sciences in Lublin
}

\begin{abstract}
One of the main objectives of both local and regional development is to increase the level of satisfaction of the needs and preferences of residents, which implies an increase in the quality of life in a particular area. Therefore, it is important to define strategic directions and priorities of activities which are of key importance from the point of view of satisfying the needs of the communes' residents. Therefore, the aim of this study was to identify and analyse priority directions of expenditure in selected rural communes of the Lubelskie voivodeship in the opinion of their residents, as compared with urban and urban-rural communes. In order to achieve the research objective, a survey was conducted among the residents of selected communes of the Lubelskie voivodeship. The survey showed that according to respondents from rural communes, the priority directions of expenditure included roads and pavements with street lighting, healthcare, tourism, recreational and sports infrastructure, as well as support for the development of investment areas. Investment needs related to social infrastructure, social welfare and pro-environmental activities were also of relative importance. Respondents from rural communes more often indicated the majority of the above investment needs than respondents from urban-rural and urban communes (except for recreational infrastructure and pro-environmental measures, tourist trails in urban-rural communes and sports and healthcare infrastructure in urban communes).
\end{abstract}

Keywords: local development, rural areas, local development policy, resident needs, investment needs JEL codes: H70, O18, O21

\section{INTRODUCTION}

Development at a local and regional level is a complex and multi-faceted concept. Literature indicates various objectives of local development, which can be considered in three dimensions: satisfaction of basic needs of the population, use of possessed resources and opportunities in the immediate environment to stimulate economic development and entrepreneurship, ensuring sustainable development and efficient operation of entities and institutions in the local unit (Wojtasiewicz, 1997). In the final perspective, local development should contribute to an increase in meeting the needs and preferences of residents, and thus an increase in the quality of life of a given area. Therefore, it is important to identify the needs of residents, including needs which can be satisfied depending on the activities of local government units. This should be an indication for the commune authorities regarding the formulation of local development policy,

\footnotetext{
${ }^{1}$ Corresponding author: Akademicka 13, 20-033 Lublin, Poland, agnieszka.komor@up.lublin.pl, +4881 4610061 (270 interphone)
} 
including strategic planning. Therefore, the aim of this study was to identify and analyse priority directions of expenditure in selected rural communes of the Lubelskie voivodeship in the opinion of their residents, as compared with urban and urban-rural communes.

\section{THEORETICAL BACKGROUND}

The issues of local level development are widely discussed in literature. The very concept of local development is defined in a varied manner (Trojanek, 1994), which results from its complexity and the multiplicity of factors influencing local development. Parysek states that local development is linked to the local scale of socio-economic activity and is based on local development factors, i.e. local needs, local resources or local organisations and enterprises. It is undertaken in order to improve the material and non-material situation in a place of residence and is connected with shaping the best possible living conditions (Parysek, 2001). Local development is 'a harmonised and systematic activity conducted in a local community with participation of interested parties, the results of which serve to meet the social needs of the local population and contribute to overall progress' (Kosek-Wojnar, 2006). This development takes place simultaneously in economic, social and cultural spheres.

Strzelecki stresses that the main objective of social and economic development is to ensure the highest possible standard of living and quality of life for residents. Therefore, local development is a complex of qualitative changes of the local territorial structure concerning the quality of life of its users and the conditions of operation of business entities (Strzelecki, 2008). Brol states that the territorial self-government, as part of the development process, carries out various public tasks, which include improving the quality of life of residents and building the competitive potential of a territorial unit (Brol, 1999).

Development is a deliberate and conscious process that is influenced by public authorities through rational use of resources in possession (Sztando, 1998). Empowering local government units, as well as decision-making autonomy in the scope of freedom of choice of development goals and ways of their implementation gives communes the opportunity to man- age and conduct development policy in their area. The basic instruments of strategic management include, among others, development strategies. Due to the fact that the local government is responsible for all public matters concerning the life of residents in a given unit, the purpose of its activities should be to satisfy the needs of the local community through the implementation of current and investment tasks (satisfying the collective needs of the community is the commune's own responsibility (Act of 8 March 1990 on Commune Self-Government). Dynamic changes taking place in various areas of life lead to transformations in the needs and attitudes of residents. Therefore, the implementation of investments should respond to the growing demands of local communities regarding the offer of public services (Cymerman et al., 2015).

Therefore, it is of importance to define strategic directions and priorities of activities which are of key importance from the point of view of satisfying the needs of the communes' residents. This diagnosis should be made in the form of a survey (Sztando, 2010). Therefore, in the process of preparing and implementing the commune's development strategy, a very important role is assigned to the commune's community (Wiatrak, 2011). Active participation of residents in the development of the strategy is desirable and constitutes a behavioural component of social capital, the level of which is relatively low in Poland (WojewódzkaWiewiórska, 2015). Social activity contributes significantly to the stimulation of development processes, which poses challenges to local politics in terms of the need to build civil society (Potoczek, 2017).

\section{MATERIALS AND METHODS}

In order to achieve the research objectives, empirical research was conducted using a sociopsychological research method in the form of a survey. The research tool was a questionnaire in paper form. The survey was conducted in 2017 among the residents of selected communes of the Lubelskie voivodship (12 rural communes, 5 urban-rural communes and 7 urban communes). A total of 1,083 correctly filled in questionnaires were obtained, of which 470 were from respondents in rural communes. They constituted the source material used for the analyses under the 
present study. Among the rural communes, where the research was conducted, the following deserve a mention: Tomaszów Lubelski, Tarnawatka, Trzebieszów, Puchaczów, Łabunie, Komarówka Podlaska, Wohyń, Michów, Niemce, Wólka, Trawniki and Włodawa.

The paper uses a non-random comfortable sample selection with the use of the snowball technique. The results are presented in tabular form. Descriptive statistics, including frequency analysis, were used to interpret the results. In addition, the $\mathrm{Z}$ test statistic was used to assess statistically significant dependencies between the respondents' gender and the preferred directions of expenditure.

\section{RESULTS AND DISCUSSION}

As part of the survey, respondents were asked to indicate which investments or activities in the commune should be financed in the first place. The respondents could indicate three most important - in their opinion - directions of expenditure. As a result of the survey, it was found that roads and pavements were the most frequently indicated directions of expenditure in the communes by respondents from the analysed rural communes of the Lubelskie voivodeship (Table 1). Over $47 \%$ of the respondents considered this type of investments to be a priority. Unmet needs in the area

Table 1. Directions of expenditure in the opinion of residents of analysed communes (\%)

\begin{tabular}{|c|c|c|c|c|}
\hline Specification & $\begin{array}{c}\text { overall } \\
(n=1083)\end{array}$ & $\begin{array}{c}\text { rural } \\
(n=470)\end{array}$ & $\begin{array}{l}\text { urban-rural } \\
(n=240)\end{array}$ & $\begin{array}{c}\text { urban } \\
(n=373)\end{array}$ \\
\hline Roads and pavements & 42.2 & 47.2 & 45.4 & 33.8 \\
\hline Healthcare & 28.2 & 28.5 & 26.3 & 29.0 \\
\hline Tourist paths, e.g. bicycle paths & 21.0 & 22.8 & 26.7 & 15.0 \\
\hline Street lighting & 12.2 & 18.3 & 9.6 & 6.2 \\
\hline Recreational infrastructure (playgrounds, activity areas) & 17.5 & 16.4 & 19.2 & 18.0 \\
\hline Development of investment areas & 14.0 & 16.0 & 14.2 & 11.5 \\
\hline Other tourism infrastructure & 13.4 & 15.1 & 12.1 & 12.1 \\
\hline Social infrastructure (day care centres, meeting places) & 12.7 & 14.5 & 12.9 & 10.5 \\
\hline Taking care of green areas & 13.7 & 12.8 & 14.6 & 14.2 \\
\hline Social welfare & 9.3 & 11.5 & 6.7 & 8.3 \\
\hline Sports base/infrastructure (pitches, courts, other) & 10.3 & 10.9 & 5.4 & 12.9 \\
\hline Support for renewable energy sources & 10.6 & 10.2 & 11.3 & 10.7 \\
\hline Extracurricular activities for children and young people & 8.3 & 10.2 & 10.4 & 4.6 \\
\hline Modern solutions in administration (e.g. e-Office) & 10.2 & 10.0 & 10.0 & 10.5 \\
\hline Housing & 8.6 & 9.4 & 7.9 & 8.0 \\
\hline Educational base/infrastructure (schools, pre-schools) & 8.5 & 8.5 & 10.0 & 7.5 \\
\hline Municipal infrastructure (sewerage, water supply) & 6.8 & 7.7 & 9.6 & 4.0 \\
\hline Cultural and artistic activities & 8.0 & 7.0 & 10.0 & 8.0 \\
\hline Car parks and parking spaces & 14.3 & 6.6 & 24.6 & 17.4 \\
\hline Drainage and flood protection infrastructure & 3.2 & 3.6 & 3.3 & 2.7 \\
\hline Environmental protection infrastructure & 2.1 & 1.9 & 2.9 & 1.9 \\
\hline
\end{tabular}

Source: own study based on research. 
of street lighting were reported by $18.3 \%$ of respondents from rural communes. It is worth noting that respondents from rural communes more often pointed to needs in the scope of construction and modernization of roads and pavements, as well as street lighting than respondents from urban and urban-rural communes. This may indicate a lower level of satisfaction of this type of needs in rural areas of the Lubelskie voivodeship in comparison with areas with a higher level of urbanisation.

Another important direction of expenditure in the opinion of respondents from the analysed rural communes of the Lubelskie voivodeship was healthcare (28.5\% of answers). It is worth noting that this share was higher in rural communes than in urban-rural communes, but slightly lower than in urban communes.

According to respondents, an important group of investment needs were expenditure on tourist and recreational infrastructure, as well as sports infrastructure. Needs regarding the construction of tourist paths (including bicycle paths) were indicated by $22.8 \%$ of respondents from the analysed rural communes, recreational infrastructure (e.g. playgrounds and activity zones) $-16.4 \%$, other tourist infrastructure - $15.1 \%$, sports infrastructure (e.g. playgrounds, courts, other) $-10.9 \%$. Respondents from rural areas were slightly more prone to indicate the need for this type of investment expenditure than residents of urban and urban-rural communes (except for recreational and sports infrastructure in urban communes). It should be noted that investments of a sports and recreational nature constitute a special group of investments, which can be connected with the term 'social innovation' (Słocińska, 2016).

For $16 \%$ of respondents from rural communes, support for development of investment areas was important. It should be stressed that respondents from rural communes more often pointed to the need for this type of investment than respondents from other types of communes. This seems particularly important in the context of increasing investment attractiveness and supporting the development of entrepreneurship in rural areas. This is valuable due to a relatively low level of investment attractiveness of rural areas in the
Lubelskie voivodeship (Godlewska-Majkowska et al., 2017).

According to respondents, a relatively important direction of expenditure was social infrastructure (day care centres, meeting places) $-14.5 \%$ of answers, and social welfare $-11.5 \%$. The needs, in this respect, were relatively more frequently reported in the investigated rural communes than in other types of communes. Expenditure on pro-environmental measures, in the form of taking care of green areas, were indicated by $12.8 \%$ of respondents, and obtaining energy from renewable sources by $10.2 \%$ of respondents. It is worth noting that the needs of investment in this area were relatively more frequently indicated as a priority by respondents from urban-rural and urban communes than rural communes. This may indicate a lower level of environmental awareness of the rural population and the need to intensify educational activities in this area. This is particularly important in the context of the involvement of the public in the implementation of sustainable development at a local level (Giordano, 2005).

Moreover, $10.2 \%$ of respondents from rural communes considered financial support for extracurricular activities for children and youth as important, and another $10.0 \%$ - modern solutions in administration (e.g. e-Office). In the light of literature, factors related to education and the efficient flow of information are considered elements that create an environment supporting innovation in a given area (Dziekański and Pawlik, 2011).

The remaining directions of expenditure were considered by respondents from rural communes of the Lubelskie voivodship as less important (less than $10 \%$ of the answers). These include: housing, educational and municipal infrastructure, cultural and artistic activities, car parks and parking spaces, drainage and flood protection infrastructure, and environmental protection infrastructure.

In the next stage of the research, an analysis was made of the dependencies between the directions of expenditure and the gender of respondents from rural communes (the studied population consisted of $60 \%$ women and $40 \%$ men). Using the $\mathrm{Z}$ test statistics to compare the column ratios, no statistically significant 
Table 2. Directions of expenditure in rural communes vs gender of respondents (statistically significant differences) $(\%)$

\begin{tabular}{|l|c|c|c|c|}
\hline Specification & Women & Men & Overall & Z Test \\
\hline Healthcare & 32 & 23 & 28 & B \\
\hline Sports base/infrastructure & 8 & 15 & 10 & A \\
\hline Municipal infrastructure & 6 & 11 & 7 & A \\
\hline
\end{tabular}

A - statistically significant difference between indications of men and women (higher percentage of men); B - statistically significant difference between indications of men and women (higher percentage of women).

Source: own study based on research.

dependencies between the direction of expenditure and gender were identified for most expenditure categories. The distribution of answers in the category of women and men was similar.

Statistically significant differences were confirmed using the $\mathrm{Z}$ test with regard to expenditure on: healthcare, sports infrastructure and municipal infrastructure (Table 2). The research has shown that women are more likely than men to indicate the need for investment in healthcare. It is worth noting that men, more often than women, considered financial support for sports and municipal infrastructure to be important.

\section{CONCLUSIONS}

The basic objective of local development is to provide residents with the highest possible standard of living and quality of life, which gives rise to the need to identify and analyse the needs of the local community. The aim of this study was to identify and analyse priority directions of expenditure in selected rural communes of the Lubelskie voivodeship in the opinion of residents, as compared with urban and urban-rural communes. The paper uses a non-random comfortable sample selection, therefore the studies cannot be representative of the entire population of municipalities.

The survey showed that according to respondents from rural communes the priority directions of expenditure included roads and pavements with street lighting, healthcare, tourism, recreation and sports infrastructure, as well as support for the development of investment areas. Investment needs related to social infrastructure, social welfare and pro-environmental activities were also of relative importance. Respondents from rural communes more often indicated the majority of the above investment needs than respondents from urban-rural and urban communes (except for recreational infrastructure and pro-environmental measures, tourist trails in urban-rural communes and sports and health care infrastructure in urban communes). As a result of the study concerning respondents from rural communes, for the majority of categories of expenditure, no statistically significant dependencies between the direction of expenditure and gender were identified. Analyses have shown that women are more likely than men to indicate the need for investment in healthcare; whereas men are more likely than women to point to the need for financial support for sports and municipal infrastructure.

\section{REFERENCES}

1. Brol, R. (ed.) (1999). Zarządzanie rozwojem lokalnym [Managing local development]. Wydawnictwo AE we Wrocławiu, Wrocław. p. 47.

2. Cymerman, J., Kola-Bezka, M., Komor, A., Konieczna, J., Stawska, J., Zapotoczna, M. (2015). Nowe wyzwania samorządu lokalnego w dobie kryzysu [New challenges for local government in times of crisis]. Texter, Warszawa.

3. Dziekański, P., Pawlik, A. (2011). Elementy rozwoju lokalnego [Elements of local development]. Uniwersytet Jana Kochanowskiego w Kielcach, Kielce.

4. Giordano, K. (2005). Planowanie zrównoważonego rozwoju gminy $\mathrm{w}$ praktyce [Planning the sustainable development of a commune in practice]. Wydawnictwo KUL, Lublin. 
5. Godlewska-Majkowska, H., Komor, A., Pilewicz, T., Turek, D., Zarębski, P., Czernecki, M., Typa, M. (2017). Atrakcyjność inwestycyjna regionów 2017. Województwo lubelskie [Regional Investment Attractiveness 2017. Lubelskie voivodship]. Institute of Enterprise of the Warsaw School of Economics, SGH, Warszawa. Retrieved from: http://www.paih.gov.pl/files/?id plik=30841 [Accessed 20.06.2018].

6. Kosek-Wojnar, M. (2006). Samodzielność jednostek samorządu terytorialnego w sferze wydatków [Independence of local self-government units in the sphere of expenditures]. Zeszyty Naukowe Wyższej Szkoły Ekonomicznej w Bochni, 4,pp. 75-88.

7. Parysek, J. (2001). Podstawy gospodarki lokalnej [Fundamentals of local economy]. Wydawnictwo Naukowe UAM, Poznań, pp. 46-49.

8. Potoczek, A. (2017). Polityka terytorialna jako polityka publiczna [Territorial policy as a public policy]. Jagiellońskie Wydawnictwo Naukowe, Torun.

9. Słocińska, A. (2016). Inwestycje w infrastrukturę sportowo-rekreacyjną jako przejaw innowacji społecznych w gminach wiejskich [Investments in the Sport and Recreation Infrastructure as a Symptom of Social Innovations in Rural Municipalities]. Handel Wewnętrzny, 6 (365), pp. 399-409.

10. Strzelecki, Z. (2008). Gospodarka regionalna i lokalna [Regional and local economy]. Wydawnictwo Naukowe PWN, Warszawa.

11. Sztando, A. (1998). Oddziaływanie samorządu lokalnego na rozwój lokalny w świetle ewolucji modeli ustrojowych gmin [The influence of local self-government on local development in the light of the evolution of communes' system models]. Samorząd Terytorialny, 11, p. 12-29.

12. Sztando, A. (2010). Wzorzec procedury budowy strategii rozwoju jednostki samorządu lokalnego [Model of the procedure for building a local government's development strategy]. Zeszyty Naukowe Wyższej Szkoły Bankowej w Poznaniu, 31, pp. 99-109.

13. Trojanek, M. (1994). Oddziaływanie władzy lokalnej na efektywność przedsięwzięć inwestycyjnych [Influence of local authorities on the effectiveness of investment projects]. Zeszyty Naukowe AE w Poznaniu. Series 2. Prace Habilitacyjne, 137, 144 pp.

14. Ustawa $\mathrm{z}$ dnia 8 marca $1990 \mathrm{r}$. o samorządzie gminnym [Act of 8 March 1990 on Commune Self-Government]. Journal of Laws 1990 No 16, item 95.

15. Wiatrak, A.P. (2011). Strategie rozwoju gmin wiejskich. Podstawy teoretyczne, ocena przydatności i znaczenie w przemianach strukturalnych obszarów wiejskich [Development strategies of rural communes. Theoretical basis, evaluation of usefulness and significance in structural changes of rural areas]. IRWiR PAN, Warszawa.

16. Wojewódzka-Wiewiórska, A. (2015). Partycypacja mieszkańców w tworzeniu strategii rozwoju gminy jako przejaw kapitału społecznego na obszarach wiejskich [Participation of inhabitants in building commune development strategy as a manifestation of social capital in rural areas]. Prace Naukowe Uniwersytetu Ekonomicznego we Wrocławiu, 401, pp. 577-586.

17. Wojtasiewicz, L. (1997). Czynniki rozwoju lokalnego - nowe ujęcia metodologiczne [Local development factors - new methodological approaches]. Biuletyn KPZK PAN, 177, pp. 7-18. 